\title{
MONGOL ADMINISTRATION IN GREATER ARMENIA
}

$$
\text { (1243-1275) }
$$

Besides political context, the issues of Mongol-Armenian relations cover another aspect, the administrative and economic issues as well. As has been said previously, Cilician Armenia was not conquered by the Mongols and, from the time of Möngke Khan, the country maintained a degree of independence, both politically and economically. With regard to the taxes paid by the Cilician Armenians, to my knowledge, contemporary Armenian sources do not explicitly mention any of them even briefly. However, from what is mentioned by Hamd Allāh Mustawfî Qazvīnī, it is understood that Cilician Armenia paid an annual tribute of 30,000 dinars to the Il-Khanid treasury at least by the end of the Il-Khanid period. ${ }^{1}$ In comparison with the 400,000 dinars that was paid annually by the Seljuk Sultanate to the Mongol court, ${ }^{2}$ the Cilician Armenian tribute looks much lighter. Of course, like the other vassal states of the Mongol Empire, besides paying the annual tribute, Cilician Armenia was obliged to supply troops to support Mongol military actions.

While the sources do not mention Mongol taxes levied on the Cilician Armenians, they explicitly discuss those imposed on Greater Armenia. In order to stress the importance of this point, I would like to draw attention to the actual policy of Mongol taxation in Greater Armenia, specifically regarding an examination of the military and administrative institution called darughachi, which has a duty of taking a population census. A survey of the various taxes and tributes levied in Greater Armenia during the Mongol period could help in our understanding of situation.

\footnotetext{
Qazvīnī, 1915:100.

2 Melville, 2009:51-101.
} 


\section{Darughachis in Greater Armenia}

The matter of economic sustainability became a vital concern for the Mongols with their expansion into northern China, Transoxiana, Khurasan and then the Caucasus, when the time for plunder and rich booty was over. Controlling and ruling these lands necessitated the establishment of a governing system. The complexity of this administrative measure, or the ruling over semi-sedentary and sedentary societies, was in fact a new challenge for the Mongols themselves. The Secret History of the Mongols records:

After conquering the Sarta'ul [Muslim] people, Chinggis Khan issued a decree placing resident commanders (darughachis) in all different cities. From the city of Ürünggechi [Gurganj] came a father and son, called Yalavachi [Yalavach] and Mashut [Mas'ūd] of the Hurumsi [Qurumchi] clan of the Sarta'uls. They told Chinggis Khan about the custom and law of the balghasun [city]. ${ }^{3}$

To judge from this passage, the Mongols were keen to learn about sedentary culture. Indeed, based on their experience in dealing with Chinese cities like Namjing and Jingdu from $1214,{ }^{4}$ and after having found new ways of governing the cities of Central Asia, the Mongols put forward the idea of establishing an administrative institution, which could evolve from a military machine into a civilian office. This was the system of governors called darughachis, which was also introduced in Armenia. ${ }^{5}$ The structure of this system varied in each country, based on local conditions. ${ }^{6}$

${ }^{3}$ MNT, 2004:92(\$263). Mahmud Yalavach, a Khwārazmian Turk, was in charge of administering most of East and West Turkestan. In 1241, he was put in charge of North China. His son Mas'üd Beg replaced him as the Mongols' chief administrative officer in Central Asia (Allsen, 1983:252).

${ }^{4}$ MNT, 2004:85-86(\$251-253); SHM, 2001:238-240. Namjing (Nanjing) is present day Kaifeng in Henan Province (Onon Urgunge, 2001:239). Later in 1234, Ögedei Khan appointed resident commanders in these cities (MNT, 2004:96[\$273]; Ostrowski, 1998:262-263).

${ }^{5}$ Darugha is a governor, and the Turkic-Mongol suffix chi indicates the agent who performs the function (Ostrowski, 1998:262). Cleaves suggests that darughachi or darugha constitutes one of the key terms in the administrative vocabulary of thirteenth to fifteenth century Mongolian texts (Cleaves/Darugha, 1953:238).

${ }^{6}$ Buell considers that, though it is certain that the first darughachis were appointed by the Mongols for China (seemingly as early as 1214), the area of the Mongol Empire, in which the darughachi system was first fully developed was Turkestan (Buell, 1979:133). 
Before discussion of the darughachis institution, we should consider how the Mongol Empire was organised. The eventual administrative division of the Mongol Empire among the sons and relatives of Chinggis Khan formed separate successor states called ulus. ${ }^{7}$ The number of uluses was not limited only by the territories of Chinggis Khan's four sons. The territories given to Chinggis Khan's brothers and the rest of his family members were uluses as well. ${ }^{8}$ Chinggis Khan gave all the lands to the west of the Irtysh, the Aral Sea and the Amu Darya to the Ulus of Jochi. ${ }^{9}$

However, Georgia and Armenia were not included in the Ulus of Jochi. ${ }^{10}$ They were under the supervision of the Mongol noyans who were interested in keeping the Caucasus area within the orbit of the vast Mongol domain. ${ }^{11}$ It is hard to know who was in charge of Arran, Shirvan and Azerbaijan (Atrpatakan). Vașșaf states that Azerbaijan and Arran were territories of Batu and his line. ${ }^{12}$ Nonetheless, from 1236 to 1258, these territories represented separate regions ruled by a Mongol governor-general. The first Mongol governor-general in this region was Chormaghan. ${ }^{13}$ The Mongolian text of the Secret History clearly says that Chormaghan was appointed by Ögedei Khan as tamghachi, which is translated into English as 'garrison commander.' ${ }^{14}$ Rashīd al-Dīn states that Ögedei Khan sent Chormaghan to this region as lashkar-tamma along with an army of 40,000 soldiers. ${ }^{15}$ According to Rashīd al-Dīn, the lashkar-tammā was

\footnotetext{
7 On successor uluses of the Mongol Empire, see the Introduction and Jackson, 1999a:709.

${ }^{8}$ MNT, 2004:80-81(\$242-243); Jackson, 1999b:36.

9 The Ulus of Jochi or later the Golden Horde was the inheritance of Chinggis Khan's son Jochi and grandson Batu with its key base in the Pontic and Caspian steppe and its capital at Sarai. In the quriltai of 1235, it was decided to launch an expedition to Russia and Eastern Europe. In 1236, Batu started his conquest of Russia. The Golden Horde ruled over Russia until 1480 (Halperin, 1985:100).

${ }_{10}$ The initial Ulus of Jochi included the vast territories of West Siberia, Kazakhstan and the lower basin of Syrdarya (Vernadsky, 2001:144).

11 Tizengauzen, 1884:245; Vașsāf, 1856:93.

12 Vașșāf, 1856:93.

13 Juvaynī/Boyle, 1997:482-483.

14 MNT, 2004:96(\$274); SHM, 2001:267. Presumably, the institute of military governor was called in Mongolian tamghachi [tamgha + chi], the holder of the state tamgha (seal). This is different from the tamghachi as tax collector ( $c f$. Doerfer, 1965(Vol. 2):565-566.

${ }_{15}$ Rashīd al-Dīn, 1952(Vol.1, part 1):98-99. Seemingly, tammachi (tanmachi in the Yüan Shih) was in charge of the military formation called tammā, which operated as security forces in the occupied lands. There is another definition of this term, which says that lashkar-tamma was an auxiliary force that consisted of various
} 
known as the head of a special garrison of selected soldiers who were sent out from the main body of the imperial army for permanent residence in certain places. ${ }^{16}$ Regardless of the differences in the naming of this office, Chormaghan held the post of military governor.

Georgia and the territories of the Zak'arids, Greater Armenia (southern and western Armenia), along with Shirvan, Arran and Mughan, and Azerbaijan were first known as the five vilayets of Chormaghan. Within Armenia, as Grigor Aknerts'i points out, at the local quriltai (assembly) called by Chormaghan, the Mongol noyans divided Armenia into three parts: northern (Georgia and the Zak'arids' principality); inner (western Armenia); and southern Armenia. ${ }^{17}$

The Georgian and Zak'arid holdings, including Ayrarat, Siwnik' and Arts'akh, were known as the Gurjistan vilayet (province of Georgia) which had been divided into eight tumans, five of which belonged to the Georgians. The remaining three tumans were Armenian, i.e., the territories of the Zak'arids of Ani and Kars; of the Awagids in Siwnik' and Arts'akh; and of the Vagramids (Gag, Shamkor and the surrounding area)..$^{18}$ The tuman was an administrative unit, and, being derived from its basic military meaning, was able to mobilise 10,000 soldiers.

The governing model was different in each vilayet. In general, the Mongols tried to use local, already existing, social formations. ${ }^{19}$ For instance, from 1236 until 1246, the Mongols did not intervene in the governing structure of the Za'karids. In the absence of Queen Rusudan, Eastern Georgia and Armenia were ruled by the Zak'arid princes, ishkhans. ${ }^{20}$ Apparently, they were appointed as heads of tumans. ${ }^{21}$ By this, local custom coincided with that of the Mongols. Only in 1246, the Mongols brought David, the son of the Georgian

nationalities, and only the commanders were Mongols (see Doerfer, 1963[Vol. 1]:255-256; cf. Ostrowski, 1998:264-270).

${ }_{16}$ Rashìd al-Dīn, 1952(Vol. 1, part 1):99.

17 Grigor Aknerts'i, 1974:26.

18 Babayan, 1969:120.

19 Manandian, who wrote his work in Soviet times, considers that the Mongols, being nomads, in terms of social development were at a lower level than the Armenians and the Georgians, therefore they were unable to change the existing formation in all the lands they conquered (Manandian, 1952:245).

${ }^{20}$ Kirakos Gandzakets'i, 1961:263.

${ }^{21}$ According to the local terminology, the head of tumans were hākims and maliks (Babayan, 1969:120). 
King Lasha, from Caesarea; his reign lasted until 1270.22 Therefore, Eastern Georgia and Zak'arid Armenia were double vassals of the Georgian King and of the Mongol Khan. ${ }^{23}$

In contrast, by the second half of the thirteenth century, the Mongol system of ownership was introduced in southern and western Armenia, known as the vilayet of Greater Armenia. ${ }^{24}$ The Mongols used this land as their Summer and Winter base. Local governors were dismissed and the Mongol nobility owned the land as enchü / injü, a land allotted to the ruling family. ${ }^{25}$ However, within the vilayet of Greater Armenia, some principalities of the Taurus Mountains, particularly the T'ornik branch of the Mamikoneans in Sasun, and the Vaspurakan branch of the Artsrunids in Mokk and Ŕshtunik, as well as some mountainous Kurdish and Seljuk families, saved their lands by recognising the Mongol rulers and entering into vassalage. The Artsrunid island of Akht'amar, and the cities of Erzinjan (Erznka) and Khlat (Akhlāt) also preserved their autonomy. The centre of this vilayet was the city of Karin (Erzurum). ${ }^{26}$

As elsewhere, the Mongol administration in the Gurjistan vilayet set two goals in order to mobilise the wealth of all subjugated countries, to conduct a census and extract taxes. ${ }^{27}$ These goals were implemented by the new institution of governors, darughachi or basqaq.

As has been mentioned above, the term tamghachi describes a personal representative of the Khan who held the state seal tamgha, and Chormaghan, as the tamghachi of the region, exercised full power with a wide range of functions: Political, military, civil, and administrative, as well as financial. According to Kirakos Gandzakets'i, he was also a judge (yarghuchi). ${ }^{28}$ Both tamghachi and yarghuchi were appointed by the central government; they were in charge of monitoring administration and justice. ${ }^{29}$ This can be illustrated by a

\footnotetext{
${ }^{22}$ Grigor Aknerts'i, 1974:33; Orbelian, 1910:420-421.

${ }^{23}$ Only from 1256 until 1344, Armenia was a part of the Hülegü's appanages.

${ }^{24}$ Babayan, 1969:121.

${ }^{25}$ Ibid., 121. For more details on enchü (injü), see Lambton, 1953:78; Scherbak, 1997:194-195; Doerfer, 1965(Vol. 2):220-225.

${ }^{26}$ Babayan, 1969:121.

27 The identification of natural resources was also the purpose of a census (Allsen, 1987-1991:32).

${ }^{28}$ Kirakos Gandzakets'i, 1961:275. Yaruga or jaruga in Mongolian means 'lawsuit,' 'litigation,' and yarghuchi (yarugha+chi) is a 'judge' (Lessing, 1973:1037; cf. Doerfer, 1975[Vol. 4]:64-66).

29 Ratchnevsky, 1991:176.
} 
passage from the Secret History of the Mongols. When Batu, the grandson of Chinggis Khan, complained to Ögedei Khan about the claim of Güyük and his colleagues regarding the issue of seniority between Batu and Güyük, Ögedei became very angry with Güyük and refused Güyük an audience, saying:

I shall make of him a scout,

So that he must climb

City walls like mountains,

Until his ten fingernails drop off.

I shall make of him a tamghachi,

So that he must climb

Hard-pounded city walls

Until his nails of five fingers splinter. ${ }^{30}$

On the basis of what was said about Güyük, the next Great Khan, it can be supposed that the position of tamghachi was an arduous one in the echelons of power. It can also be assumed that the main duty of tamghachi was to combat and besiege cities. ${ }^{31}$

The tamghachis were supported by local governors, darughachis, the heads of garrisons left behind in conquered towns and districts. ${ }^{32}$ Juvaynī states that Ögedei Khan issued a decree (yarligh) that the leaders (سروران presumably, darughachis) and basqaqs (bāsqāqs) from every place should accompany the levy and render assistance to Chormaghan..$^{33}$ In secondary literature, the term darughachi is glossed as 'an official who is entrusted with a seal. ${ }^{34}$ Here, an issue may arise about the relative ranks of tamghachi and darughachi; nevertheless, whether tamghachi or darughachi, it relates to the institution or office created by the Mongols to interact with local society in conquered countries. ${ }^{35}$ There was no obvious trace of any similar institution functioning in the Mongol homeland, so, apparently, this office was intended to deal with non-Mongols in non-Mongol lands. The darughachis were the most important officials, exercising great power in the area to which they were assigned and they were respon-

30 MNT, 2004:97(\$276); SHM, 2001:269.

31 Ostrowski, 1998:263.

32 MNT, 2004:96(\$273-274, 281).

33 Juvaynī/Boyle, 1997:482.

34 Ratchnevsky, 1991:259(note 177); Doerfer, 1963(Vol. 1):319-323.

35 Buell's hypothesis supported by Morgan on the Khitan origin of darughachis is unproven historically and philologically (Endicott-West, 1989:151[note 55]). However, Ostrowski tends to see more Chinese influence in the origin of this institution (Ostrowski, 1998:276-277). 
sible for conducting the census, collecting taxes, being in charge of the courier service, and of levying troops from among the local people.

The Mongolian darugha or darughachi is derived from the root daru, which means to press or suppress, and could be interpreted as oppressor. ${ }^{36}$ Semantically, the Turkish equivalent of darughachi is basqaq; the Arabo-Persian version is shahna. ${ }^{37}$ In Armenian sources, it appears as ostikan (governor): 'They left evil ostikans in charge of the land,'38 or as shahna: 'They took Erznkay first of all and left a shahna. ${ }^{39}$

Since this darughachi had soldiers under his command and the office was in a transition stage from military to civil, in Armenian sources they are also referred to as chieftain (qLuuunn) or chief of chiefs (uıuuquig uıuı): 'They left a chieftain (glkhavor) called Ghara Buqa. ${ }^{40}$ In Orbelian, awagats' awag (chief of chiefs) stands for darughachi: 'Buqa, who was called awagats' awag,'41 and pasghag (basqaq): 'They have gathered in Tiflis to Arghun [Aqa], who was vazir and pasghaq [overseer] over all lands and was appointed by the great Khan. ${ }^{\prime 2}$

The official function of darughachi and basqaq was not clearly defined, although it is believed that the term basqaq was used in the eleventh century. ${ }^{43}$ Scholars claim that darughachi and basqaq are recorded separately ${ }^{44}$ and that the rank of basqaq was subordinate to that of darughachi. ${ }^{45}$ This view has been based more on which nation-

${ }^{36}$ For more on darugha, see Cleaves, 1953:237-255; Vernadsky, 1953:211-212, 219-220; Doerfer, 1963(Vol. 1):319-323; Vásáry, 1978:201-206; Allsen, 1981:41; Morgan, 1982a:129; Ostrowski, 1998:262-277.

${ }^{37}$ Juvaynī/Boyle, 1997:44(note 3), 105(note 24); Morgan, 1990:108-109. Some scholars refer to darughachis as the officers in charge of taxes and to shahnas as civil governors (Grekov, 1953:686). The term daruga was used in Șafavid Administration (Minorsky, 1943:141).

${ }^{38}$ Kirakos Gandzakets'i, 1961:361.

${ }^{39}$ Grigor Aknerts'i, 1974:30.

40 Ibid., 23.

${ }^{41}$ Step'annos Orbelian, 1910:430. Buqa Chink'san[k], from the Jalayir tribe, rebelled against Arghun Khan and was killed by the latter in 1289 (Step'annos Episkopos in Hakobyan, 1951:49).

${ }^{42}$ Step'annos Orbelian, 1910:412.

43 On the origin of the institution of basqaqs, see Vásáry, 1978:201-206.

${ }^{44}$ Endicott-West in her study of the office of darughachi (ta-lu-hua-ch'ih) in China, believes that the functions of the offices of basqaq and darughachi varied (1989:18-19, 35).

${ }^{45}$ Spuler, 1943:303; Vásáry, 1978:201; Ratchnevsky, 1991:138-139. 
alities held this office rather than on the basis of function. ${ }^{46}$ Some explain that darughachis were Mongol persons or persons regarded as equivalent to the Mongols, ${ }^{47}$ while basqaq were local officials. ${ }^{48}$ Others say that a darughachi was often a Uighur and sometimes a Persian. ${ }^{49}$ Summing up these views, it can be said that darughachis possessed the authority to take decisions and dealt with administration in general, while the routine work of administration was delegated to basqaqs..$^{50}$ According to Chinese sources, the taxation system in China was based on the homestead principle, therefore darughachis were appointed by Ögedei Khan in order to control the situation in addition to local tax collectors. ${ }^{51}$ As elsewhere, the Mongols adopted a policy of appointing two government officials to one post in order that they could control each other. In the case of Greater Armenia, this post was assigned to Oirat Arghun Aqa and Jochid Töre Aqa (T'ora Agha in Armenian sources). ${ }^{52}$

The governors or darughachis were assigned to deal with the administrative problems of the whole city or region under the supervision of the rulers. The general scheme of Mongol administration in Zak'arid Armenia, before its annexation to the Il-Khanate had the following structure (1236-1256/58):

Great Khan

- Georgian King

- Princes (ishkhans) or heads of tumans

In other parts of Greater Armenia, it was as follows (1248-1256/58):

Great Khan

- Governor-General (tamghachi)

- Darughachi / basqaq

${ }^{46}$ Though the roles of the offices often overlapped, one suggests that tammas (Mongol) and basqaqs (Persian and Turkic) were military overseers, while shahnas (Persian) and darughachis (Mongol) were civilian officers (Ostrowsky, 1998:262277; Lane, 2003:166).

${ }_{47}$ Initially, at the time of setting up the Il-Khanate, Oirat Arghun, known as Arghun Aqa and Uigur Körgüz were entrusted with great power ( $c f$. Morgan, 1990:109-110). For Chinese examples, see Endicott-West, 1989:86-87.

${ }^{48}$ Ratchnevsky, 1991:138.

${ }^{49}$ Grousset, 1970:243.

${ }^{50}$ Lambton, 1953:424. Basqaqs' main duty was the inner protection of the subjugated lands and this institution lasted in Rus' until the 1320s (Vásáry, 1978:201; Vernadsky, 1953:220).

${ }^{51}$ Munkuev, 1965:47.

52 Kirakos Gandzakets'i, 1961:261-262. 
In the successor states, it was as follows (1256/58-1344):

\author{
Great Khan \\ - Blood prince (ruler of Ulus) \\ - Darughachi / basqaq
}

The actual number of darughachis in the Caucasus is unknown. In some areas of the empire, the number of officials was high. For example, in 1231, when the Korean capital Kaesong had been taken by the Mongols, 72 darughachis were placed under the Mongol protectorate to run it. ${ }^{53}$

The whole institution of darughachis / basqaqs was set up to maintain a far greater use of population and natural resources. This system applied to Georgia and Armenia right from the beginning of the conquest, based on the Mongols' prior experience of this institution in China.

As elsewhere, the establishment of the institution of darughachi in Armenia had far-reaching consequences. The darughachis started to conduct a census of the population, and a registry of land, livestock and possessions. This was a starting point for the permanent economic use of Greater Armenian territories. The introduction of the Mongol fiscal administration influenced the political status of Armenia, developing it from a vilayet to an administrative province of the Mongol Empire.

\title{
Mongol Census-taking in Greater Armenia
}

The Mongol census, taken throughout the 1250s in all parts of the Mongol Empire, was a decisive moment for the regulation of the economy in the conquered lands, because it was designed to control and mobilise human and non-human resources. It had importance for Armenia as well, because it signified a new stage in the history of the Armenian people, the process of their affiliation to the Mongol Empire. Before the actual censuses, the Georgio-Armenian princes were obliged to pay tax and to provide all necessities, including horses, guides, dwellings, food and carts to the Mongol governors who held the paiza (tablet of authority). ${ }^{54}$ However, among the

\footnotetext{
53 Grousset, 1970:259.

54 Manandian, 1952:246.
} 
censuses taken in Armenia in the $1250 \mathrm{~s},{ }^{55}$ the most important census was that of 1254, which was intended to put Armenia under the central registration of the Mongol Empire.

The census of 1254 was conducted by Amir Arghun or Arghun Aqa ${ }^{56}$ and implemented by Buqa ${ }^{57}$ in Greater Armenia. In general, data collection was based on the household..$^{58}$ Unfortunately, the Armenian sources do not give any reliable details about the size of the population. According to Manandian, the number of peasants during the reign of King David VII Ulu (1247-1270), the son of Lasha, was about one million, and the whole population of Georgia, including Armenia, was four to five million. ${ }^{59}$ However, the Armenian sources are very informative in terms of the sex or age of people entered in the Mongol registers. The youngest was eleven, ${ }^{60}$ or fifteen $^{61}$, and the oldest was sixty years old. ${ }^{62}$ The registers covered all the male population and excluded women. ${ }^{63}$ However, according to some sources, taxes were levied on women and children as well. ${ }^{64}$

The entry of women and children later into the Mongol rolls can be explained by the fact that the registration of the male population was carried out separately, and the reason for this is the utilisation of manpower for military service. An anonymous Georgian chroni-

55 According to Vardan Arevelts'i there was a Mongol census-taking in Armenia in 1243/1244 (Vardan Arevelts'i, 1991:147-148). This information seems plausible, since there was a census taken in Iran in 1240 (Allsen, 1987:130).

${ }_{56}$ Arghun's father Taichu was the Commander of a Thousand (Juvaynī/Boyle, 1997:505). Rashīd al-Dīn states that Arghun's father, whom he does not name, in time of famine, sold his son in exchange for a leg of beef to a certain Kadan of the Jalayir tribe (Rashīd al-Dīn, 1952[Vol. 1, part 1]:95). For Arghun' career, see Lane, 1999:458-482, 2003:177-212. Kolbas identifies Arghun Aqa as the man who shaped Iran in the middle period of Mongol rule (Kolbas, 2006:121).

${ }^{57}$ Buqa was from the powerful Jalayir tribe, and was titled Chink'san[k] ('minister' in Chinese) in 1286. Being so elevated, he sought to conspire against Arghun Khan in 1290. The intrigue was discovered and Arghun killed Buqa and all his male offspring. The Georgian King Demetre was also killed on the plain of Mughan on the bank of the River Kur, for he had married his daughter to Buqa (Step'annos Episkopos in Hakobyan, 1951:48-49). Buqa caused the Armenians great suffering, which was described by Frik, the Armenian poet of the thirteenth century, in his verse About Arghun Khan and Buqa (Frik, 1952:38-43).

${ }^{58}$ Allsen, 1987:119.

59 Manandian, 1952:251.

${ }^{60}$ Kirakos Gandzakets'i, 1961:362.

${ }^{61}$ Grigor Aknerts'i, 1974:37.

${ }^{62}$ Kirakos Gandzakets'i, 1961:362; Grigor Aknerts'i, 1974:37.

${ }^{63}$ Kirakos Gandzakets'i, 1961:362.

${ }^{64}$ Sebastats'i in Hakobyan, 1956:141; Vardan Arevelts'i, 1991:148. 
cler, relating Arghun's census of 1254, says that Arghun had to calculate the number of cavalry men and soldiers who could participate in raids along with noyans, and he registered one out of every ten peasants who had good land. ${ }^{65}$

The other anonymous Georgian source states that the Mongols were taking one man from ten peasant houses for military service. ${ }^{66}$ Northern or Zak'arid Armenia was obliged to provide 30,000 horsemen. From this account, it is estimated that the population of Zak'arid Armenia reached around 270,000 peasant houses. ${ }^{67}$

During the process of conducting the census, in the key cities, the Mongols set up so-called divans, the chancery where davtars, or registry books, were kept. ${ }^{68}$ Grigor Aknerts'i records:

A Tat'ar chieftain, Arghun by name, came by the command of Manku Ghan [Möngke Khan] and took a census of the eastern country for the taxes. From this time on, they were taking taxes according to the number of heads of the people, as many as were inscribed in the books. ${ }^{69}$

According to Orbelian, the divans were reported to be in QaraQorum, Tiflis and in Davrezh (Tabriz). ${ }^{70}$ Bitikchis, the scribes or secretaries, ran the chancery. ${ }^{71}$

The category of male adults exempt from registration was the clergy. The Armenian sources state this explicitly. By not being included in the rolls, the Armenian clergy exercised a great deal of freedom from corvée and military obligation and received immunity from poll tax. This situation was common elsewhere in the Mongol Empire, and can be considered a political tool for the Mongols to attract ecclesiastics to cooperate with them. ${ }^{72}$

Because the census imposed obligations on the registered population, such as 50 spitak or silver coins from each accounted person in Armenia, there were attempts to avoid the registration. In order to

${ }^{65}$ Manandian, 1952:251.

${ }^{66}$ Anonymous Georgian source quoted in Manandian, 1952:250-251. For common figures in Mongol raids, see Amitai, 1987:236-255.

${ }^{67}$ Grekov, 1953:682.

${ }^{68}$ Step'annos Orbelian, 1910:411,427.

${ }^{69}$ Grigor Aknerts'i, 1974:37. In China, the registry books were called blue registers (Allsen, 1987:119).

${ }^{70}$ Step'annos Orbelian, 1910:408-411, 426.

${ }^{71}$ Kirakos Gandzakets'i, 1961:275.

72 Allsen, 1987:121. 
discourage this, cruel penalties were imposed on those who attempted to escape the census-takers. ${ }^{73}$

The census pursued not only fiscal and military goals, but was also an inventory of the skills of the population. In Greater Armenia, as elsewhere in the Mongol Empire, all artisans, whether in cities or villages, were registered and taxed. ${ }^{74}$ The census was also a survey of the economic resources of empire, or in the broadest sense, it was a preparation for further conquest. ${ }^{75}$

According to Allsen, census-taking in this vast empire denoted an imperial policy geared up for the long-term systematic exploitation of subject people. ${ }^{76}$ The census of 1254 in Armenia followed this pattern and therefore had a practical result. In 1256, the Caucasus was incorporated as a part of the hereditary territories of Hülegü or the Il-Khanate. ${ }^{77}$

There were a few more censuses conducted in Armenia, probably in 1273 [1275], according to Step annos Episkopos, ${ }^{78}$ and in 1314, according to the colophons, in which it is said that, in 1314 (763 Arm.), the [Mongol] census-takers arrived in Vayots' Dzor, and they registered even a month-old child. ${ }^{79}$ At the beginning of the fourteenth century, there was almost no control coming from the central imperial administration, therefore the census-taking was conducted by the Il-Khanid court and it seems that it was carried out to include every newborn child. In this sense, the roll aimed at the policy of mass taxation to project future resources to support the Mongols' further campaigns. ${ }^{80}$

${ }^{73}$ Grigor Aknerts'i, 1974:37.

${ }^{74}$ Kirakos Gandzakets'i, 1961:362.

${ }^{75}$ Allsen, 1987:124.

76 Ibid., 125.

${ }^{77}$ Manandian, 1952:244; Babayan, 1969:153; Bedrosian in Hovannisian, 1997: $259-260$.

${ }_{78}$ Step'annos Episkopos in Hakobyan, 1951:44.

${ }^{79}$ Khach ikyan, 1950:104; Sanjian, 1969:58.

${ }^{80}$ The general poll-tax (sar-shumārā) introduced by the Mongols in Iran must not be confused with the jizya, the ancient poll-tax based on Muslim law and exacted from non-Muslims. After the Mongol conquest, jizya ceased to exist but was restored by Öljeitu in 1306 (Petrushevsky, 1968:533). 


\section{Tributes and Taxes}

The census identified the actual number of people that could be taxed systematically. The taxation itself required a system, especially if it related to vast territories like the Mongol Empire. Due to Möngke Khan, the fiscal system of the Mongols was augmented and gradually unified towards the second half of the thirteenth century. Studying the comparative perspectives of Russia and the Mongol Empire, Halperin once said that it is impossible to compare the levels of taxation in different Mongol successor states. Both Iranian and Mongol taxes flourished in the Il-Khanid territories; however, no-one can identify which was which. Surely, the Mongols would not mistakenly levy tax on furs in China or rice in Russia. ${ }^{81}$ The same can be said for Armenia. In order to introduce the economic condition of Greater Armenia during its supervision by the Mongol noyans and the Il-Khans, it is intended to list some taxes, levied by the Mongols in Armenia, which are found in the Armenian sources, and which might help to clarify the nature of Mongol taxation in conquered territories.

Among the taxes and levies that the Mongols introduced in Armenia, there was a typical Mongolian tribute called qalan and a levy called qubchur. Later, under Hülegü, a tax called taghar was brought into Armenia. ${ }^{82}$

1. As has been mentioned before, the census covered mostly the male population, although there were cases that included women, children and the elderly. ${ }^{83}$ This registration obliged the Georgian and Armenian princes willingly or unwillingly to give tribute to the Mongols in order to provide cavalry troops for Mongol military action. ${ }^{84}$ This service was called qalan or khalan in the Armenian sources. ${ }^{85}$

Qalan in Grigor Aknerts'i and Rashīd al-Dīn was rendered as a tribute of military service or a payment for exemption from Mon-

${ }^{81}$ Halperin, 1983:244-246.

82 Qupchur is khap'chur in Kirakos Gandzakets'i, 1961:374.

83 Sebastats'i in Hakobyan, 1956:141; Vardan Arevelts'i, 1991:148. Supposedly, this act of imposing tax on women and children in Armenia was questioned at the central court by Arghun Aqa (Allsen, 1987:167).

84 Grigor Aknerts'i, 1974:26.

85 Ibid., 26, 35. 
gol military service. ${ }^{86}$ The root khal (khalaa) in Mongolian perhaps meant and today means replacement, and it is usually used for the recruitment of soldiers. ${ }^{87}$ Therefore, qalan was the tribute paid to recruit soldiers on an occasional basis as was practised everywhere, including Georgia, Armenia and Iran. As was noted in Armenian sources, two men out of ten were obliged to serve in the Mongol army. ${ }^{88}$ According to this obligation, the Georgio-Armenian army participated in Hülegü's conquests of Baghdad in 1258 and Syria in $1260 .{ }^{89}$ Qalan may correspond to the Armenian tribute known as hetsel, the cavalry vassal obligations. ${ }^{90}$

2. Another Mongolian tax introduced in Armenia was qubchur, originally a herd tax. ${ }^{91}$ Qubchur (gobchur) in Mongolian meant a tribute on flocks and herds and the root qubchi still means in modern Mongolian 'to put a saddlecloth on the back of an animal. ${ }^{92}$ Originally, Ögedei Khan had decreed that each military tuman must contribute one three-year-old sheep from every herd to the royal court and one sheep out of a hundred to the poor and needy every year. ${ }^{93}$ Therefore, initially, the rate of qubchur in all conquered lands was one per cent. ${ }^{94}$ This tax grew more complicated during the Il-Khanid period, when it became a levy or additional tax imposed on the conquered population. Later, it stood as a general term for tax, in some cases meaning poll-tax..$^{95}$ Qubchur was collected many times a year if the original levy did not provide a sufficient fund, even 20 or 30 times, if we believe the Persian source. ${ }^{96}$

${ }^{86}$ However, according to Petrushevsky, qalan and qubchur in Iran were used instead of kharaj (Petrushevsky, 1968:532). The thirteenth century Persian poet Pūr-i Bahā, the panegyrist of the Juvayni family, in 1264 wrote a 'Mongol' ode that was translated by Minorky. This poem is an account of historical events that occurred on the frontiers of Khurasan with a vast number of Mongol technical terms including taxes in Iran under Mongol dominion (Minorsky, 1964c:274-305).

${ }^{87}$ Tsevel, 1966:647; Lessing, 1973:916. Qalan is also associated with another Mongol tribute called alban (Smith, 1970:48; Lambton, 1988:200).

${ }^{88}$ Grigor Aknerts'i, 1974:49; Grekov, 1953:682.

${ }^{89}$ For the campaigns of Hülegü and other Il-Khans, see Chapter 5.

90 The term hetsel is found in one of the undated inscriptions of Ani (Kostaneants', 1913:221; Babayan, 1969:251).

${ }^{91}$ For qubchur or alba qubchur, see Schurmann, 1956:325-330; Doerfer, 1963(Vol. 1):387-391; Lambton, 1988:199.

92 Tsevel, 1966:146; Lessing, 1973:363.

${ }_{93}$ MNT, 2004:99(\$279).

${ }_{94}$ Petrushevsky, 1968:530.

95 Allsen, 1987:153; Lambton, 1988:199.

${ }^{96}$ Rashīd al-Dīn, 1946(Vol. 3):248. 
It was levied in coins, in accordance with the wealth of the person and his ability to pay. ${ }^{97}$ In the case of Armenia, it was 60 spitak (silver coins) per head. ${ }^{98}$ It is worth noting that revenue collection in the form of money was preferred within the Mongol Empire, because it was economically feasible to ship cash over great distances and convert it into some other type of goods or services. ${ }^{99}$

3. Taghar was a levy on food and provisions. In West Asian sources, it also meant an extraordinary levy to sustain the imperial army while on campaign. ${ }^{100}$ Taghar in Mongolian is a sack or a bag, used mostly for provisions. ${ }^{101}$ This was a widespread tax in the territories of the Mongol Empire, where the economy was based on agriculture. The culminating point of this tax had been reached in China during the period of the Yüan Dynasty, where the taghar as a levy on crops was taken from each male head and from each land. ${ }^{102}$ The following describes taghar in Armenia:

Hülegü commanded that the tax called t'aghar be collected from each individual listed in the royal register. From such they demanded one hundred litrs [pound] of grain, fifty litrs of wine, two litrs of rice and husks, three sacks, two cords, one spitak [silver coin], one arrow, let alone the other bribes; and one in every twenty animals plus twenty spitaks. ${ }^{103}$

Juvayni relates that the dispatch of taghars of flour for provisioning the army covered an area from 'Armenia to Yezd [Yazd] and from the land of Kurds to Jurjān,' which was procured by the elchis (envoys) who were in charge of their transportation. ${ }^{104}$ The year 1256 was when Armenians played a part in the Mongol war with the Ismāîlis by providing most of the provisions for the Mongol armies. ${ }^{105}$ If all the food levies of ulagh (see further) and taghar were imposed with no exception, it seems that Greater Armenia

\footnotetext{
${ }^{97}$ Juvaynī/Boyle, 1997:517. A hexagon-shaped coinage for the imperial tax qupchur was minted in Tabriz (Kolbas, 2006:196).

${ }^{98}$ Grigor Aknerts $\mathrm{i}, 1974: 37$.

99 Allsen, 1987:172.

${ }^{100}$ Ibid., 186.

101 Doerfer, 1965(Vol. 2):512-519; Tsevel, 1966:509; Lessing, 1973:764.

102 Yüan Shih, Chapter 93, in Dalai, 2003:219.

${ }^{103}$ Kirakos Gandzakets' $i, 1961: 374-375.1$ litr of wine is equal to 2/5 litre, 1 litr of rice is $0,5 \mathrm{~kg}$ (Manandian, 1952:277).

${ }^{104}$ Juvaynï/Boyle, 1997:621. For the provisioning of large armies campaigning over extraordinary distances, see Smith, 1984b:223-228.

105 Rashīd al-Dīn, 1946:30.
} 
faced economic crisis in 1256. The repercussions of these taxes brought famine to Armenia. ${ }^{106}$

4. Besides these three major taxes, there were other taxes. One was called the tamgha, a toll on commercial goods, as well as a licence for commercial acts. ${ }^{107}$ The collector of this tax was called the tamghachi, for he put a tamgha (seal) on goods for sale, similar to a customs' stamp. ${ }^{108}$ In the Armenian inscriptions of the city of Ani, dated 1270 (719 Arm.), the tamgha was used together with the baj, the local Armenian term for the custom, or duty tax. ${ }^{109}$ The precise rate of the tamgha is not known. It was levied at varying rates and a substantial part of the revenue of the empire was derived from it. ${ }^{110}$ Initially, it was levied at ten per cent of the value of each commercial transaction. ${ }^{111}$ In 1257 , the Genoese frequently traded through Kars involving Zak' arid Armenia in the Black Sea trade. ${ }^{12}$ Caravan routes passing through Trebizond, and the cities of Erzurum, Berkri, and Khoi in Greater Armenia, were connected with the Italian trading republics. ${ }^{113}$ Apparently, this was a very profitable business for the Mongols if we consider that Hülegü's conquests were financed under the tamgha tax. ${ }^{114}$ The trade usually was centralised near the royal court, therefore the tamgha maintained the Il-Khanid court, army and civil administration. ${ }^{115} \mathrm{On}$ the other hand, the burden of the tamgha caused the Il-Khan Ghazan to cut this tax by half, from ten to five per cent of the value of each transaction in towns. ${ }^{116}$

106 Sebastats' $i$ in Hakobyan, 1956:142.

${ }^{107}$ For the tamgha, see Doerfer, Vol. 2, 564-565. For the commercial taxes in the Il-Khanate, see Pemler, 1985:157-177.

${ }^{108}$ Kirakos Gandzakets'i, 1961:277.

109 Kostaneants', 1913:221; Basmadjian, 1922:23, 337. The Armenian baj may derive from the Persian term $b \bar{a} j$, a tribute on trade ships (Rashīd al-Dīn, 1946(Vol. 3):25.

${ }^{110}$ Lambton, 1986:84 (Nuzhat al-qulūb, text 1915). Qazvīnī mentioned twenty cities in Iran where the tamgha was levied (Strange, 1919:113).

111 Petrushevsky, 1968:532.

112 Manandian, 1965:187. Armenia had had trade relations with Genoa since the beginning of the thirteenth century (Alishan, 1893:437-438).

113 Manandian, 1952:260-263.

114 Kolbas, 2006:201. Hülegü's Syrian campaign was subsidised by Anatolia as well, where the annual tribute reached the sum of 20 tumans in cash, 3,000 gold bars, 1,000 horses and mules, and 500 rugs and satin textiles (Āqsarā'̄ì, 1944:62-63, 73).

115 Boyle, 1968:508.

116 Ibid., 532. 
The basic tax terms that were used and introduced by the Mongols, namely qubchur, qalan, taghar and tamgha, had different meanings in different places. Thus, qubchur in Iran meant also a poll tax levied on the subject population. ${ }^{117}$ On every occasion that a census was held, the qubchur was reassessed. Being fixed at the rate of 70 dīnārs per 10 persons ( 7 dinnār per person) in 1258, based on a new census, the qubchur ranged in scale from 500 dinnārs for a wealthy person to one dinnar for the poor. ${ }^{118}$ Thereafter, the imposition of the census and poll tax qubchur seems to have become a regular procedure. Under Ghazan Khan, the qubchur was paid by villagers in two equal installments, at Nou Rūz and at the Autumn solstice, and by nomads only at Nou Rūz. ${ }^{119}$ In the North Caucasus, the qubchur, apart from being a cattle tax, was also a head (poll) tax, collected in coins or silk. Since these regions had no local coinage, this levy was assessed on livestock in the area. ${ }^{120}$ Qalan in Iran under Rashīd al-Dīn lost its original Mongol meaning of military duty, and was probably a levy of labour service. ${ }^{121}$ Taghar in Iran was a fodder or forage tax paid in grain, at a rate of 100 mans, which equalled one ass load. ${ }^{122}$

5. Ögedei Khan established the postal system (yams) throughout the empire to provide urgent dispatches of decrees, revenues and taxes. The arbitrary tax yam for the elchis/ìlchis (envoys, messengers) had been levied at the expense of provincial inhabitants. On this occasion, Kirakos Gandzakets'i says:

And then they [the Mongols] began to harass them [the Armenian princes] through taxation, by travelling to and fro, and by soldiership, and even more than this, they placed them under duress, but killed no-one. ${ }^{123}$

Hundreds of cavalrymen often accompanied the elchis. ${ }^{124}$ The passage of the envoys, and expenditure on their food and service were additional duties met by the local inhabitants. Kirakos continues

117 Juvaynī/Boyle, 1997:551.

118 Ibid., 524.

119 Lambton, 1953:80.

120 Allsen, 1987-1991:33.

121 Lambton, 1988:200. Qalan in Iran was used as the obligation to the ruler (Schurmann, 1956:334). Qalan and its Perso-Arabic substitute mal in the narrowest sense has a meaning of agriculture tax (Allsen, 1987:154).

122 Petrushevsky, 1968:533. Juvaynī/Boyle, 1997:609.

123 Kirakos Gandzakets‘i, 1961:263.

124 Lambton, 1953:82. 
that the Armenian prince Hasan Jalal prudently arranged his land and business for the needs of the Mongol travellers, who were coming to him, whether for food or something else; he made ready whatever he could to meet the needs of the Mongol elchis. ${ }^{125}$

6. In mentioning the tribute levied for postal couriers and their horses, the Armenian historians meant the levy called ulagha / ulägh. Ulagha existed in Mongolia until the beginning of the twentieth century and meant relay transportation. Various combinations of this term provided the Mongolian language a rich vocabulary, such as ulagha nekhekhu which meant to accompany someone travelling by relay in order to return the horses, or ulagha zar bichig that meant a travelling warrant for obtaining relay horses. ${ }^{126}$ The efficiency of couriers was a matter of special importance; therefore, in the territory of the Il-Khanate, ulagha was a tax levied at a certain constant rate every year. During the Mongol period, this tax was described by some Muslim sources as a 'national calamity.' ${ }^{127}$ The reason for such a definition may relate to the scarcity of horses available to maintain this duty in addition to the supply of horses for the army.

In addition to these taxes, during Mongol rule, there was another Mongol tax called susun or shusun (provision tax) found in the undated inscription of Shirakavan. ${ }^{128}$ There was one more tax of Mongol origin called nemeri/nemari, which in Mongolian means 'added' or 'associated.' This was an extraordinary tax abandoned by Abū Sa'îd (r. 1316-1335) which was inscribed in one of his edicts in Ani. ${ }^{129}$

${ }^{125}$ Kirakos Gandzakets'i, 1961:269.

126 Tsevel, 1966:587; Lessing, 1973:869.

${ }^{127}$ Petrushevsky, 1968:536.

128 Kostaneants', 1913:247; Manandian, 1952:284.

129 The edict is written in Persian on the walls of Manuche mosque in Ani and has no date. Barthold suggests that the date of the inscription is between 1319 and 1335, probably towards the 1330s (Barthold, 1966:319). Babayan suggests the date as 1319 (Babayan, 1969:178). The text of the edict says that according to the order of the Il-Khan, except for the tamgha, all other unlawful taxes, such as qalan, nemeri, and tarkh should be abandoned in the city of Ani and other regions of Georgia (Barthold, 1966:318). The Persian text, reproduced by Alishan, reads the tax nemari نمارى as thamadi ثمادى with the translation left blank (Alishan, 1893:56). 
In connection with the taxes, it is worth mentioning about another Mongol term tarkhan (darkhan), ${ }^{130}$ which was also found in Armenian sources; it was either juridical document verifying tax immunity or a title given to a person who was exempt from taxation. ${ }^{131}$ In addition to the clergy, rich Armenian merchants were granted tarkhan documents, like Asil Umek, who lived first in Karin, then in Tiflis; or the sons of the wealthy houses of Saravan, Shnorkhavor and Mkrtich'. ${ }^{132}$

Many taxes of non-Mongol-origin are mentioned in the sources as well. ${ }^{133}$ The mal, which was a property or possession tax, was assessed by measurement. ${ }^{134}$ According to Babayan, the mal in Armenia evolved from a land tax to a possession tax because the land tax was replaced by the qalan. ${ }^{135} \mathrm{~A}$ certain portion of revenue from the mal was divided between the local landowner and the Mongol divan. ${ }^{136}$ Interestingly, the tax on vineyards and orchards in the Armenian inscription of Talin in 1267 and in Mren in 1273 was called the khalan. ${ }^{137}$ This surely was not related to the military tax qalan we described above, since in the inscriptions of Ani in 1036, this tax had already been mentioned. ${ }^{138}$ The Muslim agriculture and land tax known as kharaj was also levied in Armenia. ${ }^{139}$ In the account of the martyrdom of St. Grigor, Bishop of Karin, it is stated that, in addition to the poll tax of seven or eight dahekans (gold coins), people paid the kharaj from the age of 12. ${ }^{140}$ The 'alafa (fodder) and the 'ulufa (food) were arbitrary taxes imposed on local populations to host visiting messengers. ${ }^{141}$

Besides these taxes, the Armenian peasant had to continue to serve corvées to his lord or the clergy, since the main husbandry of the

130 The tarkhan was exempted from obligations of tribute to his lord, and was given a certain degree of juridical immunity (Schurmann, 1956:323).

${ }^{131}$ In modern Mongolian, there are the expressions darkhan avraga, or champion of champions for wrestlers, and darkhan ber, or the daughter-in-law who gives birth to three sons successively, by which she obtains immunity for herself in the family of her husband.

${ }_{132}$ Kirakos Gandzakets'i, 1961:363; Orbelian, 1910:395.

133 Step'annos Orbelian, 1910:493; Grigor Aknerts'i, 1974:25.

${ }_{134}$ Lambton, 1988:358.

${ }_{135}$ Babayan, 1969:249.

136 Grekov, 1953:683.

137 Babayan, 1969:252.

${ }_{138}$ Kostaneants', 1913:20; Manandian, 1952:282.

139 On kharaj coinage, see Kolbas, 2006:180.

140 Ter-Davtyan, 1973:277.

141 Rashīd al-Dīn, 1946(Vol. 3):248. 
Armenians was based on labour rent. ${ }^{142}$ There were many other taxes, such as akhst'amar and kapal (commercial taxes), dŕnagir (tax imposed at the city gates), t'arkh (tribute to provide provisions for the army), kasanik (tax on artisans), aghlkak (tax on sheep), hazr ezin or hasara (tax on oxen), and hambrele (tax on cows), imposed in Armenia during the thirteenth and fourteenth centuries. ${ }^{143}$

Based on the above, it can be concluded that the Mongol tax system differed from that which existed in the sedentary societies of Armenia or Georgia before the Mongols' arrival. Mongol taxes imposed in Mongolia can mostly be classified into two major categories: tributes, levied on individuals or households and paid to their immediate lord (qalan, qubchur, taghar, tamgha); and corvées, imposed on individuals or households in order to permit the execution of some functions for the ruler or lord (ulagh, yam, nemeri).

With the establishment of Mongol rule, the taxes imposed in Armenia can be divided into four major categories: commercial taxes; land taxes; ${ }^{144}$ military corvées (occasional); and taxes with quotas set in currency, the revenues of which apparently went to the Court or the owners.

Modern scholars who are working on the fiscal system of the Mongols practised in different parts of the Mongol Empire are trying to make distinctions between tribute, levy and tax. ${ }^{145}$ This is a complicated issue but it is obvious that the Mongol taxation policy in the territories of the Il-Khanate, including Armenia, evolved from being an occasional tax based on census to a more systematic one. ${ }^{146}$

${ }^{142}$ For the main source for taxes levied in Armenia before the Mongol rule, see Mkhit'ar Gosh (1130/1140-1213).

${ }^{143}$ Manandian, 1952:281-283; Babayan, 1969:251-263.

${ }^{144}$ From the second half of the thirteenth century, land categories within the IlKhanate were changed into divan or state land; enchü or private land, given to the ruling family and nobles; vaqf, land permanently given to clergy and religious institutions; milkī or privately owned land, which could be sold and bought, inherited and presented; and $i q t \bar{a}$ ' or the military fief. In the Il-Khanate, the majority of military iqtā were in Azerbaijan: Namely in Shirvan and Gushtāsfī (the lower reaches of the rivers Kur and Arax). Gushtāsfī had an irrigation network over fields and villages. The Pīshkīn district was under iqțā', the annual revenue of which was 50,000 dīnārs, while the revenue from other districts was only 5,000 dīnārs (Qazvīnī, 1915:382, 392-396). For the iqțā system in the Islamic Middle East, see Amitai, 2001:152-171.

${ }_{145}$ For Mongol taxation, see Grekov, 1953:679-685; Lambton, 1953, 1986-1988; Smith, 1970:46-85; Sinclair, 2000:39-52.

${ }^{146}$ If the Mongol fiscal obligations in China during the Yüan Empire and in Iran after the Ghazan Khan's updated tax reform brought a unified system to these states, it did not happen in Russia (the Golden Horde) (Schurmann, 1956:309). 
A system of dual taxation existed: The Mongols levied their taxes in addition to the existing ones. The exhaustive list of taxes mentioned randomly in the Armenian sources is concluded by some of them as follows:

From those who had nothing to give, they took their sons and daughters according to demand. ${ }^{147}$

Kirakos Gandzakets'i reports that artisans, anglers, miners and manufacturers were heavily taxed. ${ }^{148}$ As has been said earlier, increased Mongol and local taxation in 1245-1246, drove some nobles from their lands and made them flee to fortresses. ${ }^{149}$ This severe taxation policy was one of the reasons for the Georgio-Armenian princes' rebellion of $1249 . .^{150}$ The Mongol tax qubchur introduced in 12591260 was a cause not only for rebellion by the Caucasian lords, but also for mortgaging their estates to pay this tax. ${ }^{151}$ The salt mine in Koghb province was a very profitable business for the Mongols probably due to the high tax on salt. ${ }^{152}$ In 1261 , some of the lords were killed because of their failure to pay tax. ${ }^{153}$ As a result of the general census in Greater Armenia taken in 1275, all tax privileges were revoked and taxes were now levied not on the household, as before, but by head, by size of property, and on cattle as well. ${ }^{154}$

Without claiming that Mongol administrative measures, introduced in Greater Armenia were systematic and that the various terminologies were fully consistent for this whole period, this chapter listed the variety of taxes levied in Greater Armenia alone because no such evidence can be found in the contemporary sources for Cilician Armenia. The Mongol period was in many ways a disaster in Greater Armenia because the control of all economic resources was the Mongols' priority. However, they were aware that, without maintaining proper economical bases, they would not have any means to sustain the conquered territories. Therefore, the reforms of Möngke Khan in 1254 aimed to stop illegal taxation by the governors

147 Kirakos Gandzakets'i, 1961:374-375.

${ }^{148}$ Ibid., 362-363.

${ }^{149}$ Ibid., 266, 313, 319.

${ }_{150}$ Grigor Aknerts'i, 1974:35; Kirakos Gandzakets'i, 1961:312-314; Melikset-bek, 1936:56.

${ }^{151}$ Kirakos Gandzakets i, 1961:362.

152 Ibid., 363.

153 Vardan Arevelts'i, 1991:152; Kirakos Gandzakets'i, 1961:390-391.

${ }^{154}$ Garsoïan, 1997:128. 
and princes for their personal aggrandisement. The Khan knew that numerous taxes might cause tax-paying subjects to escape and thus ruin the imperial economy. ${ }^{155}$ Although his policy brought order, the nature of the taxes was not altered.

The occasional taxes of a nomadic society that were extended to sedentary societies underwent some modifications. The new fiscal system comprised both traditional fiscal obligations and Mongol tributes. ${ }^{156}$ This made it easy for the two systems to exist side by side, and in fact, this double system was a heavy burden on the conquered population. ${ }^{157}$ The introduction of the Mongol fiscal administration in Armenia made possible a change in the political status of Armenia from a vilayet to an administrative province of the Il-Khanate.

The exhaustive list of Mongol and local taxes suggests that the taxation issue was a primary concern for the Greater Armenians. As the Mongol period progressed, tributes increased and this is reflected in the Armenian sources, from which the overall picture of the nature of Mongol administration is taken. A detailed classification of all tax terms and terminologies that evolved over the Il-Khanid period would require a comparison with other regions of the empire, something which cannot be undertaken here. Nevertheless, the evidence provided by the Armenian sources should be a useful addition to the detailed studies provided, for example, for the province of Fars in southern Iran. ${ }^{158}$

The hardship imposed on Greater Armenia by the Mongols can be contrasted with the much more favourable situation enjoyed by Cilician Armenia. Regardless of these, both Armenias participated in the Mongol conquest of the Middle East.

155 Allsen, 1987:144.

156 On the evolution of the Mongol revenue system, see Allsen, 1987:144-188; Schurmann, 1956:376.

157 Lambton, 1986:84.

${ }^{158}$ Lambton. 1986/1987; Aigle, 1997. 